\title{
DESENVOLVIMENTO DE MICROSSATÉLITES PARA HYALE NIGER (AMPHIPODA: HYALIDAE)
}

\author{
Siqueira, S.G.L. ${ }^{1,}$; Iwasa-Arai, T. ${ }^{1}$; Mansur, K.F.R. ${ }^{1}$; Longo, P.A.S. ${ }^{1}$ \& Leite, F.P.P. ${ }^{1}$ \\ ${ }^{1}$ Universidade Estadual de Campinas (UNICAMP), Campinas, \\ Laboratório de Interações entre Comunidade Marinhas. \\ *Autor correspondente: silvsbio@gmail.com
}

Hyale niger (Haswell, 1879) é uma das espécies mais abundantes de anfípodes associados à macroalgas do gênero Sargassum C. Agardh no litoral do estado de São Paulo. A biologia reprodutiva e dados populacionais da espécie em diferentes costões do estado são bem conhecidos, contudo a distribuição disjunta, compartilhada por registros no Brasil e na Austrália, gera discussões acerca das identificações de $H$. niger na costa brasileira. Neste sentido, uma abordagem molecular pode representar uma alternativa para a validação da espécie e na delimitação de suas populações. Os marcadores microssatélites constituem uma ferramenta importante para responder diversas questões em taxonomia, genética de populações e conservação, sendo a sua utilização em organismos marinhos ainda pouco explorada. Portanto, o objetivo do estudo foi desenvolver um conjunto de microssatélites para a espécie Hyale niger. Vinte sete indivíduos de Hyale niger coletados associados à Sargassum no litoral de São Sebastião (SP) foram utilizados para a construção de uma biblioteca enriquecida de microssatélites. O DNA genômico foi obtido a partir de indivíduos inteiros por um método de extração salina e fragmentos de DNA foram ligados a adaptadores de fita dupla 5'-CTCTTGCTTACGCGTGGACTA-3' e 5'-TAGTCCACGCGTAAGCAAGAGCACA-3'. O enriquecimento foi feito pela captura baseada em hibridização com sondas biotiniladas e os fragmentos selecionados foram amplificados por PCR e clonados em vetores. A transformação foi feita em células competentes $\mathrm{DH} 10 \mathrm{~B}$ com plasmídeos recombinantes e cultivados em uma cultura ágar+ampicilina+galactosidase. Colônias únicas foram transferidas para microplacas a $-70^{\circ} \mathrm{C}$ após incubação a $37^{\circ} \mathrm{C}$. por 12 horas. Uma placa de 96 clones positivos foi sequenciada e 29 motivos foram identificados. Um total de 12 pares de primers complementares foram selecionados, de acordo com o comprimento dos primers entre 18 e 22 pb, temperatura de anelamento entre 45 a $65{ }^{\circ} \mathrm{C}$ e conteúdo de GC acima de $35 \%$. Com a validação desses 12 marcadores moleculares será possível avaliar os microssatélites polimórficos possibilitando estimar as frequências alélicas da população Hyale niger de São Paulo. Desta forma, os resultados serão uteis para analisar da estrutura genética entre diferentes populações, fornecendo informações acerca da conectividade, distanciamento genético entre as populações e sobre questões relacionadas à taxonomia da espécie $H$. niger.

Palavras-chave: algas, fauna associada, genética de populações, marcador molecular, Peracarida. 